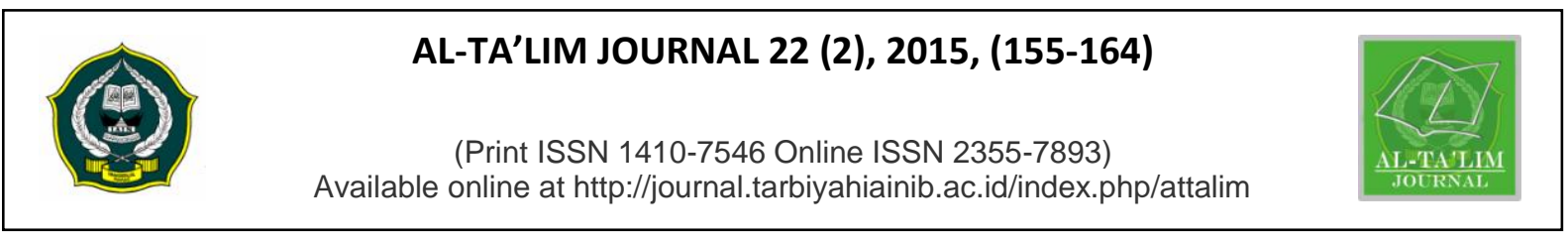

\title{
Transformation of the Minangkabau Islamic Education: The Study of Educational thought of Abdul Karim Amrullah, Abdullah Ahmad And Rahmah El-Yunusiyah
}

\author{
Zulmuqim \\ Department of Islamic Studies, Faculty of Education and Teacher Training IAIN Imam Bonjol Padang \\ e-mail: zulmuqim@yahoo.co.id \\ DOI: http://dx.doi.org/10.15548/it.v22i2.139
}

Received: 11th April 2015; Revised: 10th July 2015; Accepted: 18th July 2015

\begin{abstract}
Transformation of education in Minangkabau at the Beginning the $20^{\text {th }}$ Century was done by established figure of Islam, such as Abdul Karim Amrullah, Abdullah Ahmad and Rahmah el-Yunusiyah. Abdul Karim Amrullah begins transforming Islamic education by changing the status of Surau Jembatan Besi to become Islamic modern school (Madrasah) with class system, which is known as Sumatera Thawalib. Abdullah Ahmad transforms Islamic education by establishingHIS Adabiyah with school system, and also includes Islamic subjects in the curriculum. Moreover Rahmah el-Yunusiyah committed renewal by building woman Islamic school (Madrasah).
\end{abstract}

Key words:Renewal, Islamic Education, Study, Education Thinking.

\section{INTRODUCTION}

Minangkabau is the place for Minangkabau ethnic. The region is divided into three districts, they are Tanah Datar district, Lima Puluh Kota district and Agam district. The Minangkabau region is wider than today West Sumatera region. The region consists of West Sumatera Province except Mentawai, part of Jambi Province and part of Riau Province. Based on Navis opinion (1984: 1 ), Minangkabau is more famous the cultures than the state or kingdom. I DON'T UNDERSTAND THIS SENTENCE.

Before Islam arrived Minangkabau region(West Sumatera), the people refer the Minangkabau custom as their rules of life (Nasroen, 1971: 24-26). The Minangkabau people strongly adhere to their cultural values and custom. In fact, having received Islam, they still integrate Islamic teaching and their cultural values, and thus the popular term, adat
Basandi Syara, Syara Basndi Kitabullah (custom is based on religious values and religion is based on the Holly book Al- Qur an) become the motto of people in Minangkabau (Hamka, 1984: 138).

The Islamic Education Process cannot be separated from the education process which is conducted in the mosque. The term surau (mosque) was already known before the arrival of Islam. Surau in minang custom belongs to the tribe or the community and become the complementary of Rumah Gadang (the Traditional House of Minangkabau) which are used for meeting, to have a social gathering, and a place for male youth, widow and the old man to spend the night (Azra, 2000: 30). Islam spread smoothly without serious obstacles, since Islam was introduced through cultural activities, such as ethnic based performances. For example, the word Surau was not changed at all when Islam was introduced, and thus, the Minangkabau people could accept Islam 
without coercion. The first place for studying Islamic Studies was in Surau Ulakan Pariaman. This mosque was built by Syeikh Burhannudin( 1066H/1646 A.D- 1111H/1691 A.D) (Yunus, 1993: 18)

The Islamic Education Process cannot be separated from the education process which is conducted in the mosque. The term surau (mosque) was already known before the arrival of Islam. Surau in minang custom belongs to the tribe or the community and become the complementary of Rumah Gadang (the Traditional House of Minangkabau) which are used for meeting, to have a social gathering, and a place for male youth, widow and the old man to spend the night (Azra, 2000: 30). Islam spread smoothly without serious obstacles, since Islam was introduced through cultural activities, such as ethnic based performances. For example, the word Surau was not changed at all when Islam was introduced, and thus, the Minangkabau people could accept Islam without coercion. The first place for studying Islamic Studies was in Surau Ulakan Pariaman. This mosque was built by Syeikh Burhannudin( 1066H/1646 A.D- 1111H/1691 A.D) (Yunus, 1993: 18)

The education process in Surau was done through the instructional approach known as halakah, that is the student sit with legs cross surrounding the teacher while listening and repeating what the teacher say. Besides, the students also sit face to face for learning the holly Book selected by the students. The leaning material in Surau is usually related to Fiqh (Islamic Deed) Arabic, Hadith (the prophet saying) tafsir(Qur an Translation ) and Taswuf ( mysticism).

Since the 1900s the second wave of the Islamic education transformation in Minangkabau (West Sumatra) was run by the youth , the student of Syeh Ahmad Khatib alMinangkabawi. He was the Minangkabau youth who reached the highest level in teaching the religion, who was appointed to Imam ( leader) mahzab Safi'i in Masjidi Haram (Noer, 1994: 38-39). The transformation that was done by the youth is the transformation of surau to become a modern School like Islamic School. The renewal shifted the classical of Halakah System. The Change was also followed by the increasing of general courses in madrasah and improving religious courses in the general school, including the changing of learning methods.

Among the transformation figures in Islam Education is Syekh Karim Amrullah leading Sumatra Islamic School of Tawalib in Padang Panjang. Syekh Abdullah Ahmad leading Adabiyah School in Padang, and Rahman El-Yunusiah leading DiniyahPutri (Islamic School for female student) in Padang Panjang. This article is aimed at exploring their biography, especially their commitment in transforming Islamic education.

\section{FINDINGS AND ANALYSIS}

\section{Abdul Karim Amrullah}

a. His Biography and Activities.

Syeh abdul Karim Amrullah was born on 10th February 1879 in Sungai Batang. Maninjau West Sumatra and died when he was 66 years old on 2nd of July 1945 in Jakarta (Edwar, 1981: 123). When he was young he learned Al Qur-an and was taught by Muhammah Shalih and Haji Hud in Tarusan Pesisir Selatan. One year later he learned various types of knowledge in religion from his father (Syekh Amrullah) in Sungai Batang, Maninjau. He when to Mecca at the time he was 15 upgrading his knowledge about Islam. He had been living in Mecca for 7 years (18941901) and learned from several teachers such as Syekh Ahmad Khatib, Syekh Taher Jalaludin Syekh Muhammad Jamil Jambek (the Three teachers are from Bukittinggi) Syekh Abdul Hamid, Syekh Usman Serawak, Syekh Umar Bajened, Syeh Shalih Bafadal, Syekh Hamid Jedah, Syekh Sa'id Yamani (Amrullah, 1927: 1). After went back from Mecca in 1901, he was legally appointed as a Young Ulama (Top Islamic Leader) which entitled Syekh Tuanku Nan Mudo while his father entitled 
Tuanku Nan tuo with a ceremony (Amrullah, 1927: 1). Tuanku Nan Tuo with his old classic ideology and Tuanku Nan Mudo with his New Ideology.

1904 Abdul Karim Amrullah went again to Mecca for the second time and returned in 1906. He went to Macca for the second time after his father asked him to go and took his father with him. During that visit, he had a very good opportunity to teach halakah in Syekh Muhammad Nur Al-Khalidi in Samiyah permitted by Ahmad Katib. One of his students who came from his hometown is Syekh Ibrahim Musa Parabek and Syekh Muhammad Zain Simabur (Amrullah, 1927: 69). The two students took part in supporting the transformation movement of Islamic education in West Sumatera.

Abdul Karim Amrullah was a leader who did not agree withTarekat, even though his father was the leader of $\underline{\text { Tarekat }}$ Naqsyabandiyah. The difference of both father and son make him rebellious. By contrast, his father did not feel interrupted by him. In fact his father was highly proud of him due to his knowledge (Nazwar, 1983: 70). In case of his effort to explain the view of Islam to the Tarekat, he wrote two books about Islam . First, Izhaar Asaathir al-Mulhidin fi Tasyabbuhihim bi al-Muhtadiin, in 1908, This book made a claim on the Tarekat Naqsybandiyah. Second, Qathi'u Riqab al Mulhidin fi Aqaid al-Mufsidiin, in 1914, this book made a counter opinion on Tarekat Syatariyah.

Since 1911, Abdul KarimAmrullah settled in Padang Panjang and led Pengajian (a forum of Islamic preacher) SurauJembatanBesi (Kayo, 1970: 5). Although he still used the so called traditional teaching approaches in his teaching, Hallaqah (both teacher and student sit on the floor while having a teaching and learning process), he has made a change in several cases. For example, to let students think freely by initiating discussions or debates. He gave his student chance to discuss many topics and issues about religion. During discussion, all of the students were required to share or give their reasonable ideas which are based on the holly Qur'an and Hadith (Daya, 1990: 86).

In the process of its development, SurauJembatabBesi came into a transition to be a modern Educational Institution, Madrasah Tawalib or Madrasah Tawalib in 1918. Soon after it was done, the same school also developed, The Islamic school Tawalib in Parabek, Padang Japang, Sungayang, Maninjau, KubangPutih and so on. The visions of the school is to produce Muslim scholars to be qualified in many important field, such as preacher, journalist, trader, and so on. They were spread out not only in west Sumatera but also in many places outside Sumatera, Java, Kalimantan and Sulawesi. Together with Abdullah Ahmad, Abdullah Ahmad built a Magazine Incorporation Al- Munir, 1911- 1915 in Padang. The magazine was published to improve the readers' knowledge and to facilitate the youth develop their transformation ideas. He also established a magazine incorporation Al-Munirel-Manar in Padang Panjang with ZainuddinLabay elYunusi in 1918 (Yunus, 1993: 83).

In addition, in 1917, he went to Java. He met HOS Cokroaminoto the prominent Figure of Serikat Islam in Surabaya, and Ahmad Dahlan, the founder of Muhammadiyah in Yogyakarta. KH. Ahmad Dahlan used to read his articles Published in Al-Munir (Hamka, 1982: 115). In 1918, together with Abdullah Ahmad, Syekh Muhammad Jamil Djambek Bukuttinggi, Zainudi Labay El-Yunusi and with many teachers, he built The Islamic Religion Teacher Training Institute of Sumatera (PGAI) (Edwar, 1981: 116).

In 1925 he went to Yogyakarta. He met an important figure of Muhammadiyah, H.Fakhruddin. They shared about the Islam development in their respective villages. He was interested in Muhammadiyah because its ideology is much more suitable with the Holly Qur an and Hadist. Beside, the principles include all aspects, running the educational process by building the schools, to do charity by helping the poors and the orphans (Hamka, 
1982: 148). According to Taufik Abdullah, what Abdul Karim had done, Introducing Muhammadiyah in West Sumatra (Minangkabau) in 1925 is a link that cannot be separated from the total struggle of Islamic transformation in Minangkabau (Abdullah, 1971: 66).

In 1926, Abdul Karim Amrullah together with Abdullah Ahmad was appointed to be the ambassador of PGAI of Sumatera to Egypt to attend the Islamic Conference in Cairo. Based on the records which were acquired by the committee, consisted of Alumni of AL Azhar University, The congress led by Syekh Husain Wali, they were entitled a Doctor (Doctor Honoris Causa) in Islamic Study. Then both of them met the Egyptian transformation prominent Figure Saat Zaghul Pasyafor sharing some advices (Hamka 1982: 70).

In struggling to spread Islam, he with all of his friends, against the ordinance of teachers in Minangkabau (Suminto, 1985: 51). His Strong idealism is on provoking the transformation of Islamic education, through which Muslim could prosper in their lives. For Amrullah, the objective of education is to empower students' critical thinking, in which they are able to offer solutions for problems in communities.. His struggle for education transformation sent him to preson. In 8 august 1941???, he was isolated by the Ducts to Sukabumi. He was accompanied by his wife, Dariyah and his youngest son Abdul Wahud. During his life in isolation, he remained a counselor on Islamic matters, especially those who were active in Muhammadiyah /AisyiahSukabumi.

b. The Educational Ideas of Abdul Karim Amrullah

1) The Education transformation from surau to Modern Islamic School System.

After joining Surau Jembatan Besi in Padang Panjang in 1906 and became the leader in 1911 Abdul Karim find the weaknesses of Halakah, that is only focusing of listening to teachers idea. He believed that this kind of instruction does not develop students' critical thinking. In his response to this condition, Abdul Karim Amrullah combined the Halaqah with discussion methods. As a result, the students can understand the lesson very well, since the students are required to explain and answer questiond from other students. The debating clubs regularly improve as this combination were well accepted by many communities. He promoted the spirit of discussion, independence thoughts, deeply comprehending the lesson, and reinforced students to have critical conversations with teachers (Ramayulis and Nizar, 2010: 225).

In addition to using the modern methods, Abdul Karim Amrullah also proposed the idea of building a classroom so that instruction could study in a classroom. He tended to create this idea because the student must stay at the same level, the same ability and ages. According to Deliar Nur, firstly the education process was run by applying Halakah inside the classroom system was formally recognized in 1916. Beginning from the lower class, Medium Class, and higher class. Finally kept developed and form as what is Called Modern Islamic Boarding School Tawalib Padang Panjangin 1918 (Nur, 1994: 53).

The learning materials of Surau Jembatan Besi was similar to those used at schools across West Sumatra, which focus on the learning of Al-Qur`an, Fiqih, Tafsir, and Nahwu Syaraf. After transforming itself into a modern Islamic school, it revised its curriculum. The curriculum included Islamic and General Science. The courses are: Fiqih, Arabic, Nahwu, sharaf, Tauhid, tafsir, Hadist, muhaddasah ma'ani, al'bayan, al-badi', mantik, usul fikh, the history of Islam culture, the science world, and algebra (Yunus, 1993: 75).

2) Including the Modern Literature (new) into the Curriculum

The other Abdul Karim Amrullah's idea in transforming Islamic education is using many types of the modern Books as the learning resources. The books Are: Durusul Fiqhi, Fiqhil Wadhih, Mu'inul Mubin, Al- 
Muhazzab, Qawaidul Lughah al-Arabiyah, Nahwul Wadhih, Balagah Wadhihah, Jawahirul Balaghah, Durusul Lughah alArabiyah, Muthala'ah al-Haditsah, Qiraa `atur Rasyidah, Muhadatsah al-Arabiyah, Durusut Tauhid,Jawahirul Kalamiyah, Husunul Hamidiah, Rasalatut Tauhid, Khazin, Tafsir Muhammad Abduh, Hadits Arbain, Jawahirul Bukhari, Musthalah Hadits, Manthiqul Hadits, Muzakkirat Usul Fiqh, Al-Sulam, al-Bayan, Husul Makmul (Yunus, 1993: 77).

\section{3) Using Literature (Magazines and Books)}

AbulKarim Amrullah was aware that literature, books and magazines, were important media to share his idea, thought, and some other important information in addition to giving a public speech. In its relation to the ready published book, he had written more than 18 books and many articles (Zulmuqim, 2001). He also built a magazine published $\mathrm{Al}$ Munir (1911-1915). By using this media he could explain the answer of the public questions that was related to religion, tarekat, uhsalli, bid ah problem, khurafat and so on (Noer, 1994: 47). It means that Abdul Karim Amrullah believed that books and magazines were important resources and media in the process of Islamic Education.

\section{Syekh Abdullah Ahmad}

a. His Biography and Activities

Abdullah Ahmad was born in Padang Panjang in 1878 Dandien in Padang 1933. His father is Hajji Ahmad, known as an important Ulama and trader, while his mother came from Bengkulu. His Primary school was accomplished in the Colonial School of Netherlands in Padang Panjang. He received his Islamic education from his Father. In 1895, when he was 17 years old, he went to Mecca and returned in 1899 (Noer, 1994: 46). In addition, he taught religion in Mecca at Surau Jembatan Besi Padang Panjang. He had also actively preached in many mosques around Padang Panjang and Bukittinggi. The point of his da'wah (lesson) was gaining the renewal in comprehending Islam and against bi'dah, Khurrafat and tarekat.

In 1906 Abdullah ahmad moved to Padang. Besides, teaching at Masjid Ganting (a well known and big mosque in Padang) replacing his uncle (H. Halim), he was active in doing his preaching activities. Abdul Ahmad made the renewal on Islamic education, changing from the traditional system become the modern one. One of the results was to build the AdabiyahSchool in 1909. According to Mahmud Yunus, this is the first Indonesian school that used chairs, table and blackboard in teaching and learning process. In 1915 the school became HIS Adabiyah. In fact, this School also included the religious courses in the curriculum (Yunus, 1993: 63).

To support the teaching and learning process at school besides convincing the Netherlands government, Abdullah had appointed four Nethderlands Teachers and two certified Indonesian Teachers as well as HIS teachers. After completing some evaluations finally this school was approved by the Netherlands government to be one of HIS schools which were built by the Islamic organization. A year later, this school was also paid by the Netherlands government. In school Abdullah Ahmad taught two hours a week (Steembrink, 1994: 39-40). The transformation of Islamic education was done by changing the system. He transformed Surau into School resembles Netherlands' Schools. It means that this educational system was a general school institution, not Islamic school institution but it includes religious education in its curriculum

Abdullah Ahmad is also known as an Islamic journalist. He established the $\mathrm{Al}$ Munir with Abdul Karim Amrullah, Muhammad Dahlan Sutan Lebak, and Haji Muhammad Thyib Umar in Padang from 1911 to 1915 . The magazine which was published twice a week aimed at helping the leaders and communities in general to seek Allah's guidance on their religious as well as worldly matters. The magazine also aims at encouraging Muslims to improve their knowledge, in order to enable them improve 
their life conditions. This media was also used to defend Islam from various kinds of accuses and misunderstanding (Daya, 1990: 47). The magazine contains various types of Information on general knowledge like the science of earth, astronomy, and health, but religious issues were hardly covered. (Daya, 1990). This magazines reached readers in Sumatera, Java, Sulawesi, Kalimantan and Malaya (Hamka, 1982: 101).

According to Deliar Noor, in 1914 Abdullah Ahmad was appointed as the chairman of Journalist association in Padang. He had a strong connection with the student of Secondary Schools in Padang, doctors in Jakarta who gave their help in The Jong Sumatera Bond. Besides establishing the AlMunir Magazines, he also built Al-Akbarin 1913 and became the editor in chief in $\mathrm{Al}$ Islam in 1916 which Publish by Sarekat Islam (Noer, 1994: 47).

In 1918 Abdullah Ahmad built the Association of Islamic Religion Teacher, and acquired the legal status from the Netherlands government in 7 July 1920. The beginning of PGAI association was starred by the conference Ulama (Islamic Leaders) conference of Minangkabau in Surau Jembatan Besi Padang Panjang. The purpose of the organization is to unite the traditional Ulama and the modern one. Unfortunately this purpose was not fully reached, because The old Ulama set other similar organization IttidalUlama ( The United Ulama) led by SulaimanAr-Rusuli (Yunus, 1993: 93). In 1925 Ahmad Abdullah was sent to Cairo with Hajji Abdul Karim Amrullah as the ambassador of Muslim people in Minangkabau to present at International Congress that was held by $\mathrm{Al}-$ Azhar University to discuss issues related to the collapse of Khalifah in Turkey. Both Ambassadors were entitled Doctor HonourisCausa by AklAzhar University (Yunus, 1993). According to KarelSteembrick, he became a famous Islamic cleric, but he was known more as educationist than as the Muslim cleric. People argue that he did have a major role in building the Adabiyah School. The reason is that the education in surau is integrated into western Educational System
(Steembrink, 1994: 41). The challenge is faced by the Ulama, (the Muslim cleric-old generation). They seem not to be prepared to receive the changes, while young Muslims seem to accept this idea

b. The educational Idea of Abdullah

1) The Changing of Educational System from Surau to School

Abdullah Ahmad found that the instructional system implemented in surau, such as Halaqah was no longer relevant to today's educational societies.. For that reason, Abdullah ahmad suggested that adopting Dutch instructional system in a way could improve instructional process in Islamic schools. The Netherlands Education system, with its classification like HIS (HollandscheInlandse School) was transformed into Islamic modern School. His idea was realized in 1909. The school changed into basic school that used HIS System, improved the Islamic courses and al-Qur'an. In 1915 the school become Hollandsche Malaische School Adabiyah (HMS Adabiyah) or Hollandsche In landsche School Adabiyah (HIS Adabiyah) that was helped financially by the government (Noer, 1994: 52).

2) The Even Distribution on Education.

It is very important for Indonesian children to taste the education the period of colonialism. Those who have are European children, china, and Arabian while there was no chance for the indigene. This condition pushed Abdullah Rahmad to build a State School, modified into Islamic School, HIS Adabiyah (Nata, 2000: 15). Abdullah Ahmad gave the opportunity for children regardless of their religious and social background.. In other words he did not make a strong line on the background differences of the students.

\section{3) Modification on Curriculum}

It is Islamic courses and to learn $\mathrm{Al}$ Quran that make HIS Adabiyah and HIS built by the Netherlands differently. So, HIS Adabiyah used the whole curriculum used by 
the Netherlands school it requires the school to teach religion and Al-Qur'an every week (Nata, 2000: 19).

\section{4) Reaching The Government Accreditation.}

By strong efforts, Abdullah Ahmad developed the HIS Adabiyah education and finally made a result and record. One of the examples is reaching and accreditation from the Government of Netherlands Other helps from the Netherlands was providing 3 teachers from the Netherlands, and 1 headmaster 2 teachers in common (Daya, 1990: 83). This indicates that Abdulllah Ahmad is a good school manager, in which he was able to manage the process of schooling and established good relationship with the Netherlands.

\section{Syaikhah Rahmah EI-Yunusiah}

a. The History Life and the activities

Although women once has a lack of opportunity to have decent formal education, Rahmah El-Yunusiah could manage to have good education. Her spirit to get knowledge was very strong. She engaged in independent learning. Formally, she learned at a school that was built by her sister, Zainudin Labai ElYunusi, a Diniyah School. For Rahmah, she regarded her sister as a teacher who always gave her guidance and motivation. Besides, she also thought that her sister is a great ulama, known as renewal educational figures on Islamic education system. She is also competent in some foreign languages, such as English, Arabic, Dutch and it help her understand many kinds of literature. Rahmah paid her great respect to her sister. She thought that Labay is an Inspiring person, a supporter of her will and a teacher for her.

Rahmah El-Yunusiah and his three friends, Rasuna Said, Nanisah and Jawana Basir used to go to study and attended for the Islamic Preaching that was held by Syekh Abdul Karim Amrullah (Haji Rasul), tuanku mudo abdul Hamid Hakim, Syekh Muhammad Jamil Jambek, Syekh Abdul Latif Rasyid, Syekh Daud Rasyidi, in the mosque where a man used to be the preacher. Besides getting knowledge on religion, she also learned Arabic. Unfortunately, the three ladies were insulted by people due to the condition that doesn't allow females to study (Daya, 1990: 207). Beside the religion knowledge that she got, Rahma also learned midwifery, health P3K (First Aid) from Dr. Sofyan Rasyad, Dr. Tazar in Kayu Tanam, Dr. A. Shaleh in Bukittingi, and Dr. Arifin in Payakumbuh (http://abusufyansyirboni.wordpress.com/2012/ 12/19/tokoh-pendidikan-perempuan-islamrahmah-el-yunusiyah/,THIS SHOULD BE IN REFERENCE LIST retrieved on Agustus, 8 2014). She also attended on a midwifery course in the Public Hospital in Kayu Tanam and she got a license from doctor.

When she was 16 years old, she got married to a modern young ulama, H.Baharudin Latif. After 6 years of marriage, they did not get any children. The couple considered to get divorce. From that time, she dedicated her attention and energy by running the social activities on education. Rahmah ElYunisiah planned to build a special school for female. This idea came after she find her life difficult in getting the educational service. She found the imbalance in the male and female ability because they were not equally treated. She found the fact when she has her education at Dinniyah Putri School. The female students did get a clear and satisfactory explanation about "woman". The teacher (usually a male) did give a brief explanation about religion to female student, on the other side the girls were not eager to ask questions, whereas girls as it is known have very complicated problem in nature. According to Rahmah, a woman has a great influence in life. She argued that a woman is as the first educator for her children and play her rules as a wife. To improve the female education quality she suggested that there must be a special school for woman which is taught by woman too. This fact pushed her to keep studying and someday in her dream she would build a school in which both the teachers and the student are female.

She told this desire to her sister, Labay. Labay responded this positively. She tell it also 
to her friends, the students association of Diniyah School (PMDS), fortunately they did support to this idea. 1 November1923 this school, Madrasah Diniah Li al Banat officially started led by Rangkayo Rahmah ElYunusiyah in Masjid Pasa Usang. This first year was filed by the 71 middle age woman. At that time the learning system was done by Halaqah, they only learn religion and Arabic Grammar. Along its development, the school began to apply modern educational system, teaching religion knowledge and general classic science besides improving some types skill (Nata, 2000: 30)

Due to her strong willingness, the Diniyah Li Al - Banaat (DiniyaPutri) has a significant improvement. In 1926 she opened Menjesal School, a program that was dedicated to those who cannot read and write. In 1934 she was also successfully, build kindergarten, (Freubel School) and junior School (The same level of HIS). She also built Diniyah Putri for Seven Year, four years for elementary and three years for Junior High School.

Her success in managing the school attracted the Rector al Azhar Universty, Dr. Syaikh Abdurrahman Taj. Then he visited the school in 1955. He adopted the system that was implementedin Diniyah School because Al Azhar did has any specific school program for woman. Then, some years later, the Al Azhar University built Kulliat Al- Bannat as a part of this university. As he raise a respect Rahmah, the rector of Al Azhar University Entitled Rahmah a Syaikhah(Doctor Religious Studies). Earning this title, put Rahmah at the same position with Syekh Mahmoud Syalthout, the Former Rector of Al Azhar University, who visited Indonesia in 1961. Hamka stated that this highest title used to be given to a male expert on religion (Syeikh). As far as Hamka can identify, there had been one can acquire the title except Rahmah in the world of Islam.

Rahmah El-Yunisiah has given a great contribution on Islamic Education transformation in West Sumatra and Indonesia. The Dutch, Cora Vreede and De Stuers, Stated that her Idealism can be seen in two different points of view. First, as stated by Ki Hajar Dewantoro, the founder of Taman Siswastated that she is considered as an individual figure who does not come from an organization. Second, She was put in a same position with Kartini, Dewi Sartika, who did their struggle for woman's public spaces through education.

b. The educational Idea of Rahmah ElYunusiah

1) The Changing of Educational System on Education from Surau become Female Islamic Shcool.

Rahmah did the new changes on education from surau, in which there were only male student can attend the learning process become the modern school, both sexes are the same in the treatment. In her opinion, it is a major need to be fulfilled that if a country wants to improve woman quality, there must be a special school for woman. Her desire was finally accomplished after she built Diniyah $L i$ Al-Bannat (DinniyahPutri) 1 November 1923 in Padang Panjang.

2) Woman has an Equal Right on Education

The Period of colonialism created a distinction on the woman right on education. They could not get full attention and tasted the education, besides getting insulted by people. Those kinds of pressure make Rahmah Yunusiahto try to take efforts to equalization on Education for both male and female. Rahmah found that the differences on female and male ability was due to inequality on the education opportunity. Getting a support from Zainudin Labay El-Yunusi (her brother) she built a well concerned organization on woman, Teaching Al-Qur'an, Menjesal School for illiterate woman, Freuble School (kidergaten) Junior School (the same as HIS level) and Diniah School for seven years. In 1937, she built Kulliyat al- Mu'Allimat al-Islamiyah to educate the Pre- Service Teacher in three years. She built Education Faculty and Proselytizing in 1936 and School of Tenun.

3) Women as the First Educator for children 
She realized that a mother as the first educator of the children. She saw that education in the household (informal education) is the basis for the development of a child. According to her, it would be impossible for a child to grow and develop properly when the first educator (his mother) could not take care of the children properly. She illustrated that the household is the pillar of the community, and the pillar of society of a country. Based on that statement, to increase the quality and improve the position of women, they required special education for woman taught also by a woman. To support the ability of women in organizing life in the household with a husband and children, Rahmah ElYunusiah include the educational skills for pupils of Diniyah Putri, such as cooking skills, needlework, home industry, sport and health in addition to the science of religion and Arabic (Ramayulis and SamsulNizar, 2010 243).

\section{CLOSING}

Based on the above description it is understood that the transformation $r$ of Islamic education in the Minangkabau started with a change in the education system of the modern education system from the Surau. There are three forms of transformation of modern education systems from surau.

First, the changes on the educational system of modern education system from surau to madrasah (Islamic School). This innovation made by Abdul Karim Amrullah madrasah Sumatera Thawalib established in 1918 in Padang Panjang. Second, changes in the education system of the modern education system into a surau in form of a school. This innovation made by Abdullah Ahmad finding the school of Adabiyah (Adabiyah School/HIS Adabiyah) in 1915 in the field.

Third, The reform of the educational system on modern education in the form of a surau madrasah for women. This new system wasperformed by Rahmah of El-Yunusiah by building Diniah School ( DiniyahPutri) in 1923 in Padang Panjang.

\section{REFERENCES}

Abdullah, Taufik. (1971). Schools and Politics: The Kaum Muda Movement in West Sumatra (1927-1933). Ithaca, New York: Cornell University.

Amrullah, Abdul Karim. (1927). Tafsir alBurhan.Fort de Kock: Drukkerij Baru.

Azra, Azyumardi. (2000). Pendidikan Islam Tradisi dan Modernisasi Menuju Milenium Baru. Jakarta: Logos.

Azwar, Akhira. (1983). Ahmad Khatib Ilmuan Islam di Abad ini. Jakarta: Panjimas.

Daya, Burhanuddin. (1990). Gerakan Pembaharuan Pemikiran Islam: Kasus Sumatera Thawali. Yogyakarta: Tiara Wacana.

Edwar (ed.). (1981). Riwayat Hidup dan Perjuangan 20 Ulama Besar Sumatra Barat. Padang: Islamic Centre.

Hamka. (1982). Ayahku: Riwayat Hidup Dr. H. Abdul Karim Amrullah dan Perjuangan Kaum Agama di Sumatera. Jakarta: Uminda.

(1994). Islam dan Adat Minangkabau. Jakarta: Pustaka Panjimas.

Kayo, H.M.D. Datuk Palimo. (1970). Sejarah Perguruan Thawalib Padang Panjang. Padang Panjang: Yayasan Thawalib Padang Panjang.

Nasrroen, M. (1971). Dasar Falsafah Adat Minangkabau. Jakarta: Bulan Bintang.

Nata, Abudin Nata. (2000). Tokoh-Tokoh Pembaharuan Islam Indonesia. Jakarta: Raja Grafindo Persada.

Navis, A.A. (1984). Alam Terkembang Jadi Guru: Adat dan Kebudayaan Minangkabau. Jakarta: GrafitiPers

Noer, Deliar. (1994). Gerakan Moderen di Indonesia 1900-1942. Jakarta: LP3ES. 
Ramayulis dan Samsul Nizar. (2010). Yunus, Mahmud. (1993). Sejarah Pendidikan Ensiklopedi Tokoh Pendidikan Islam. Islam di Indonesia. Jakarta: Hidakarya Jakarta: Quantum Teaching. Agung.

Steembrink, Karel A. (1994). Pesantren, Madsarah, Sekolah: Pendidikan Islam dalam Kurun Moderen. Jakarta: LP3ES.

Suminto, Aqib. (1985). Politik Islam Hindia

Zulmuqim. (2001). Pembaharuan Islam di Indonesia Awal Abad XX: Studi Terhadap Pemikiran DR. H. Abdul Karim Amrullah. Yogyakarta: Disertasi IAIN Sunan Kalijaga.

Belanda. Jakarta: LP3ES. 